\title{
Molecular mechanism of size control in development and human diseases
}

\author{
Xiaolong Yang ${ }^{1}$, Tian $\mathrm{Xu}^{2,3}$ \\ ${ }^{I}$ Department of Pathology and Molecular Medicine, Queen's University, 88 Stuart Street, Kingston, Ontario, Canada K7L 3N6; \\ ${ }^{2}$ Howard Hughes Medical Institute, Department of Genetics, Yale University School of Medicine, Boyer Center for Molecular \\ Medicine, 295 Congress Avenue, New Haven, CT06536-0812, USA; ${ }^{3}$ Institute of Developmental Biology and Molecular Medicine, \\ Fudan-Yale Center for Biomedical Research, School of Life Science, Fudan University, Shanghai 200433, China
}

How multicellular organisms control their size is a fundamental question that fascinated generations of biologists. In the past 10 years, tremendous progress has been made toward our understanding of the molecular mechanism underlying size control. Original studies from Drosophila showed that in addition to extrinsic nutritional and hormonal cues, intrinsic mechanisms also play important roles in the control of organ size during development. Several novel signaling pathways such as insulin and Hippo-LATS signaling pathways have been identified that control organ size by regulating cell size and/or cell number through modulation of cell growth, cell division, and cell death. Later studies using mammalian cell and mouse models also demonstrated that the signaling pathways identified in flies are also conserved in mammals. Significantly, recent studies showed that dysregulation of size control plays important roles in the development of many human diseases such as cancer, diabetes, and hypertrophy.

Keywords: size control; cell proliferation; cell size; insulin signaling; Hippo-LATS signaling

Cell Research (2011) 21:715-729. doi:10.1038/cr.2011.63; published online 12 April 2011

\section{Introduction}

Differences in size are one of the most prominent features among various animals, yet the molecular and genetic mechanisms that control organ or organism size are largely unknown. To date, we know that we are larger than a dog or a mouse, but we do not know why. We know that our left eye is exactly the same size as our right eye, and our brains or hearts can grow to an exact size big enough to do their job yet small enough not to impinge on other organs, but we do not know how. Many questions on the mechanism of size control remain to be answered.

Before proceeding into further discussion, it is necessary to clarify some of the concepts regarding size control. As shown in Figure 1, a hierarchy of cellular processes can be envisioned to shape the size of an or-

Correspondence: Xiaolong Yang ${ }^{\mathrm{a}}$, Tian $\mathrm{Xu}^{\mathrm{b}}$

${ }^{\mathrm{a}}$ Tel: +613-533-6000

E-mail: yang@cliff.path.queensu.ca

${ }^{\mathrm{b}}$ Tel: +203-737-2623

E-mail: tian.xu@yale.edu ganism. In general, the final size of an organ or an animal is determined by the number and size of the cells it contains and the space between the cells. In general, the space between somatic cells in animals is similar. Therefore, differences in organ or organism size between animals of the same or different species reflect differences in cell number, cell size, or both. Consistently, organ growth is the consequence of an increase in cell number, cell size or both. Cell number is determined by the balance between cell proliferation and cell death, while cell size depends on cell growth. During development, mitogens such as EGF or PDGF stimulate cell proliferation whereby cell division is propelled by the replication of DNA content and progression of the cell cycle. In contrast, cell death is a genetically programmed process in which cells commit suicide by inducing DNA fragmentation and protein degradation. Cell death can be triggered by developmental cues or lack of survival factors such as interleukin 3 to negatively regulate cell number (Figure 1). Cell growth, which depends on extracellular growth factors such as insulin, entails protein synthesis and organelle biogenesis, leading to an increase in cell mass or size. Thus, size control can be seen to be regulated by ex- 


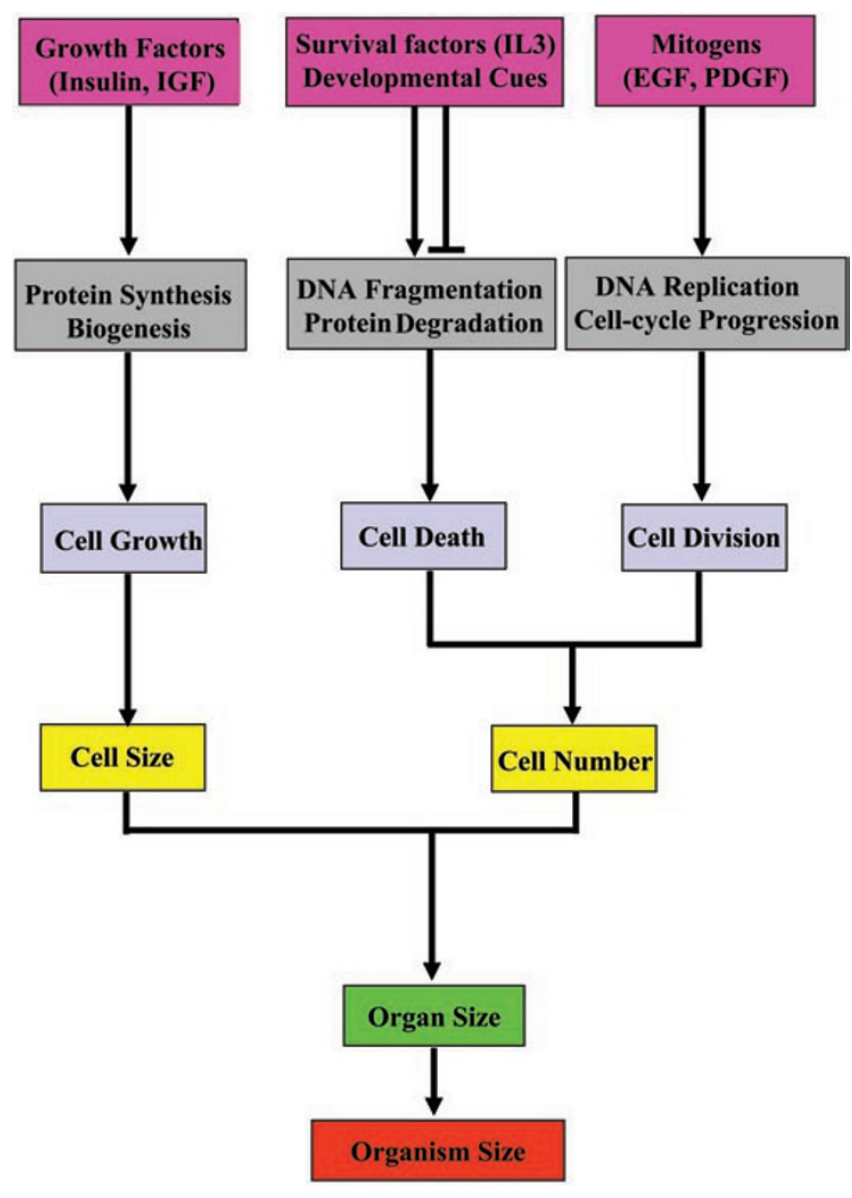

Figure 1 Hierarchy of size control.

tracellular and intracellular factors that impinge on three main points of control occurring at the cellular, organ and organismal levels.

The first clue that there exists a size control mechanism comes from studies on organ transplantation and regeneration in animals. For example, when a fetal newt limb or a rat kidney from a small species was transplanted to an adult of a larger species, the organ grew to a size characteristic of the small donor [1,2], suggesting that the size of an organ is determined autonomously by a mechanism intrinsic to the donor organ primordia. On the other hand, when a liver from a large dog was transplanted into a smaller dog, its size gradually decreased until the size of the liver became proportional to the new body size [3]. Conversely, when a baboon liver was transplanted to a human, the transplanted intact liver of the baboon rapidly grew in size until it reached the size of human liver [3-5], indicating that the size of liver can be also controlled non-autonomously by a mechanism outside the transplanted liver that is intrinsic to the host. In another set of regeneration experiments, a Drosophila imaginal disc or a rat liver can regenerate to its original size following partial removal of its mass by transection or amputation $[6,7]$. The above experiments strongly suggest that there exist mechanisms in animals to control organ size. Interestingly, a similar size control mechanism has also been found in plants [8].

\section{The roles of cell number changes in determining organ or organism size}

Previous studies have shown that differences in cell number usually make major contributions to the size of animals or plants $[9,10]$. We are larger than mice because we have more cells. However, how cell number is tightly controlled in order to maintain a constant size of an organ or animal within a given species is just beginning to be understood. In general, cell number is controlled by cell proliferation and cell death.

\section{The role of cell proliferation in size control}

In the past 20 years, many genes have been identified that can either positively or negatively regulate cell proliferation. However, most of the regulators of cell proliferation do not affect organ or organism size. For example, overexpression of E2F and DP in the developing Drosophila wing results in an increase in cell number, but fails to elicit a change in organ size [11]. Only a few proliferation regulators have been shown to be involved in organ or animal size control. The p27 is the most well documented cell cycle regulator that negatively regulates organ and organism size. It is a cyclin-dependent kinase (Cdk) inhibitor (CKI) that inhibits a variety of cyclin/ Cdk complexes including cyclin $\mathrm{D} / \mathrm{Cdk} 4 / 6$ and cyclin $\mathrm{E} / \mathrm{Cdk} 2$. The p27 mediates arrest at G1 of the cell cycle in response to transforming growth factor $\beta$ (TGF- $\beta$ ), contact inhibition, or serum deprivation in epithelial cell lines [12-14]. Mice deficient for $p 27$ display increased body size and enlarged organs, which contain more cells than wild type [15-17]. The increased cell number in the p27 knockout mice is the result of increased proliferation rate rather than decreased cell death or cell size. On the contrary, targeted disruption of $s k p 2$, an F-box protein ubiquitin ligase and a negative regulator of p27, results in mutant mice that are smaller in size. Apparently, this reduced animal size can also be caused by reduced proliferation of $s k p 2-/-$ cells [18]. Another gene called Six6, which is expressed for a short time during development in the retina, hypothalamus, and pituitary gland, has also been identified as an organ size controller [19]. Mice lacking six 6 contain retina and pituitary glands that are smaller than those in normal mice. Most interestingly, Six 6 was found to bind to the promoter region of $p 27$ and 
negatively regulate $p 27$ transcription. Therefore, in mice lacking six6, the levels of p27 were two to four times higher than normal, an effect, which caused decreased proliferation of epithelial cells in the retina and pituitary. The above investigations clearly indicate that p27 negatively regulates organ or organism sizes by inhibiting cell proliferation and decreasing cell numbers.

Another good example that cell number changes affect organ size through regulation of cell proliferation comes from the studies on the Drosophila tumor suppressor gene lats. The lats is a tumor suppressor identified in a Drosophila mosaic screen [20]. Cells lacking lats exhibit extensive cell overproliferation and develop into tumors in flies. Most interestingly, homozygous lats mutant larvae are dramatically larger in size due to increased cell numbers resulted from enhanced cell proliferation [21]. By using a similar mosaic screen in Drosophila, many upstream (e.g. Fat, Merlin, Expanded, Hippo, MATS, Salvador, etc) and downstream genes (e.g. Yorkie) of lats have been identified, which constitute a novel signaling pathway called Hippo-LATS pathway that plays important roles in organ size control by regulation of cell proliferation [22-30]. Most of the mammalian homologs of the components of the Drosophila Hippo-LATS pathway have been identified (Fat4 for Fat; Merlin for Merlin, FRMD6 for Expanded, MOB1 for MATS; Mst1/2 for Hippo, hWW45 for Salvador; LATS1/2 for lats; YAP or TAZ for Yorkie) [25, 31-42]. Most significantly, it has been shown that conditional knockdown of merlin, Mst1/2, or WW45 (Salvador), or overexpression of YAP in the liver results in increased liver size in mice [25, 33, 43, 44], suggesting that the Hippo-LATS signaling pathway is an evolutionally conserved pathway regulating animal organ size by regulating cell numbers.

Another mechanism by which cell number changes result in changes of organ size is preventing cell cycle exit and differentiation and thus sustaining cell proliferation [45]. For example, when a stabilized $\beta$-catenin was overexpressed in neural cell precursors the mice develop enlarged brains with increased cerebral cortical surface area and folds [46]. Detailed analysis of the transgenic mice indicated that, unlike loss of p27, $\beta$-catenin caused enlarged brain and increased the numbers of neural precursor cells by inhibiting the differentiation of these cells and keeping them in a proliferating state, rather than by increasing their cell cycle rate or decreasing apoptosis.

\section{Role of cell death in size control}

Apoptosis or programmed cell death is the major form of cell death that controls cell numbers in animal development. Therefore, it can also play an important role in maintaining the appropriate number of cells in a develop- ing or an adult organ. In general, apoptosis is controlled by pro-apoptotic ( $\mathrm{Bad}, \mathrm{Bax}, \mathrm{Bcl}-\mathrm{Xs}$, Bid, caspases, DFF45 and p53) and anti-apoptotic (Bcl-2, Bcl- $\mathrm{X}_{\mathrm{L}}$ and IAPs) proteins (for review, see reference [47]). Overexpression of pro-apoptotic proteins can induce apoptosis, whereas overexpression of anti-apoptotic proteins protects cells from apoptosis. It has been shown that mice overexpressing the anti-apoptotic gene, $b c l-2$, or deficient for the pro-apoptotic genes, caspase-9 or DFF45, have enlarged brains as a result of an increase in the number of neurons, which are normally removed by apoptosis [48-51]. Another good example for a role of apoptosis in organ size control is illustrated in the study of renal development. Renal hypoplasia is one of the renal diseases in humans. The most obvious phenotype caused by this disease is small kidneys. Genetic studies in patients with renal hypoplasia have found that the gene pax 2 is frequently mutated. Importantly, kidneys in mice heterozygous for pax 2 were only $60 \%$ of the size of their wildtype littermate kidneys. Further study demonstrated that this phenotype was caused by an increase in apoptosis of duct epithelial cells rather than by a decrease in cell proliferation [52]. Interestingly, overexpression of the pro-apoptotic gene $p 53$, which is negatively regulated by Pax2, causes small kidneys [53]. This suggests that the loss of function of pax 2 may cause apoptosis and small kidney size by increasing the effect of pro-apoptotic gene p53. Analogously, mutations in the Drosophila eyeless gene, a homolog of the mammalian pax gene, also cause large-scale apoptosis of photoreceptor precursors and the elimination of the eyes [54]. Therefore, the pax gene may play an important role in organ size control by controlling the extent of apoptosis during development.

\section{Coordination of cell proliferation and cell death in size control}

As stated above, cell number and organ size are determined by the balance between cell proliferation and cell death. Therefore, the coordination of cell proliferation and apoptosis must be highly important in maintaining a constant organ or organism size. A good example of this role of coordination in organ size control is demonstrated in liver regeneration studies. A mouse or human liver can grow back to its original size after several days even when $70 \%$ of its mass is removed. During liver regeneration, not only do the levels of proteins promoting cell proliferation (HGF, NF- $\kappa B$, cyclin D1, cyclin E) increase, but also the genes inhibiting apoptosis (Bcl2 ) are coordinately activated. This effectively results in enhanced cell proliferation and reduced cell death [55]. Livers in rats in which TGF- $\beta$ is overexpressed and cell proliferation is inhibited cannot regenerate after partial 
hepatectomy [56], indicating that enhanced cell proliferation and reduced apoptosis is of high importance for liver regeneration. Another good example, demonstrating the coordinated control of cell numbers and organ size by cell proliferation and apoptosis, was shown in tumor-promoting agent treatment experiment in liver and kidney. Treatment of liver with phenobarbital or cyproterone acetate or treatment of kidney with lead acetate could cause a dramatic increase in cell proliferation, which leads to an enlargement of the respective organ. However, withdrawal of the drug treatment leads to a dramatic increase in apoptosis, which is accompanied by a reduction of liver or kidney mass to its original size [57, 58]. Detailed biochemical analysis indicated that the level of antiapoptotic protein Bcl-2 increases during the induction of hyperplasia, but decreases after withdrawal of the drug treatment [59]. Therefore, animal can maintain a constant organ size by keeping the balance between cell proliferation and cell death.

\section{The role of cell size changes in determining organ or organism size}

Although we know that cell number difference accounts for much of the size differences among different species [10], cell size changes play a unique role in size control for several reasons. First, cells have to accumulate mass and attain a certain size before they can divide and proliferate. In another word, it is difficult to understand cell number control without comprehending how cell size is controlled. Secondly, as mentioned early, alterations in cell proliferation or cell number are not always correlated with changes in organ or organism size. We will discuss this further below. Thirdly, in many cases, cells size changes are more important than cell number changes in determining the organ or organism size. For example, $50 \%$ of the $C$. elegans body growth is due to increases in cell size during adulthood when no cell proliferation takes place [60].

\section{Cell ploidy/DNA content}

It has been recognized for a long time that cell size is proportional to DNA ploidy or nuclear DNA content in bacteria, yeast, fungi, and plant and animal cells. For example, the cell size of tetraploid animals is usually twice the size of diploid animals. In animal systems, the size of an animal organ is determined by its total mass (cell number and cell size), however, not necessarily by ploidy in many cases $[10,61]$. For example, although the cell size in a diploid salamander is twice the size in a haploid salamander, the body size for the two animals is the same because the diploid salamander contains half as many cells as the haploid [62]. However, in some situations, cell size changes caused by increased ploidy may play a part in controlling the specific size of an organ. For example, in $s k p 2$-knockout mice, liver mass can be recovered to its normal size after partial hepatectomy by increasing ploidy and cell size without any changes in cell proliferation and cell number [63]. Furthermore, in plants, an increase in ploidy can directly influence organ size [64]. For example, the fruits of banana or cotton are much larger in high-ploidy varieties than those of their diploid counterparts [65]. The molecular mechanism for increased cell or organ size with the increase in ploidy is unknown. It may be related to the expression of certain genes controlling organ or organism size $[66,67]$. Indeed, several genes $(d b l-1, L O N-1)$, which are involved in TGF- $\beta$ signaling in $C$. elegans, affect body size associated with ploidy [67]. Further studies in mammalian or other systems will shed light on the molecular mechanism of organ size control by ploidy.

\section{Insulin/PI3-kinase/TOR pathway}

An exciting advance in our understanding of size control has been the demonstration that several molecules, which are activated by insulin or insulin-like growth factors (IGFs) in Drosophila and mammals, regulate organ and organism size [68-70]. Significantly, TOR (target of rapamycin) was found to be the central player in both insulin-induced and nutrient-induced cell size changes $[71,72]$. Biochemical and genetic studies have suggested that a complex insulin/PI3-kinase (PI3K)/TOR pathway is composed of a variety of cellular genes including oncogenes, tumor suppressor genes, and protein synthesis genes controlling cell growth and cell size (Figure 2).

In this pathway, mammalian insulin or IGF and possibly Drosophila DILPs (Drosophila insulin-like peptide) bind to and activate the intrinsic typrosine kinase activity of their receptors, insulin receptor (Inr) or IGF-R. Once activated, the receptors phosphorylate IRS (insulin receptor substrate) or Chico (Drosophila), leading to the recruitment of PI3K/Dp110 (Drosophila) via the SH2 domains of its adaptor p85 or p60 (Drosophila). Binding of PI3K to IRS/Chico directly stimulates its kinase activity, which can phosphorylate the 3-position of the inositol ring of the plasma membrane lipid phosphatidylinositol (PtdIns) 4,5-diphosphate $\left(\mathrm{PIP}_{2}\right)$ to form $\operatorname{PtdIns}(3,4,5) \mathrm{P}_{3}$ $\left(\mathrm{PIP}_{3}\right)$. In Drosophila, Inr can also activate PI3K directly through the multiple dPI3K-SH2 docking sites in its extended tail without binding to Chico [73]. Signaling proteins such as serine-threonine kinase Akt (also called protein kinase $\mathrm{B}, \mathrm{PKB}$ ) and phosphoinositide-dependent kinase 1 (PDK1) accumulate at sites of PI3K activation by the binding of their pleckstrin-homology domains 


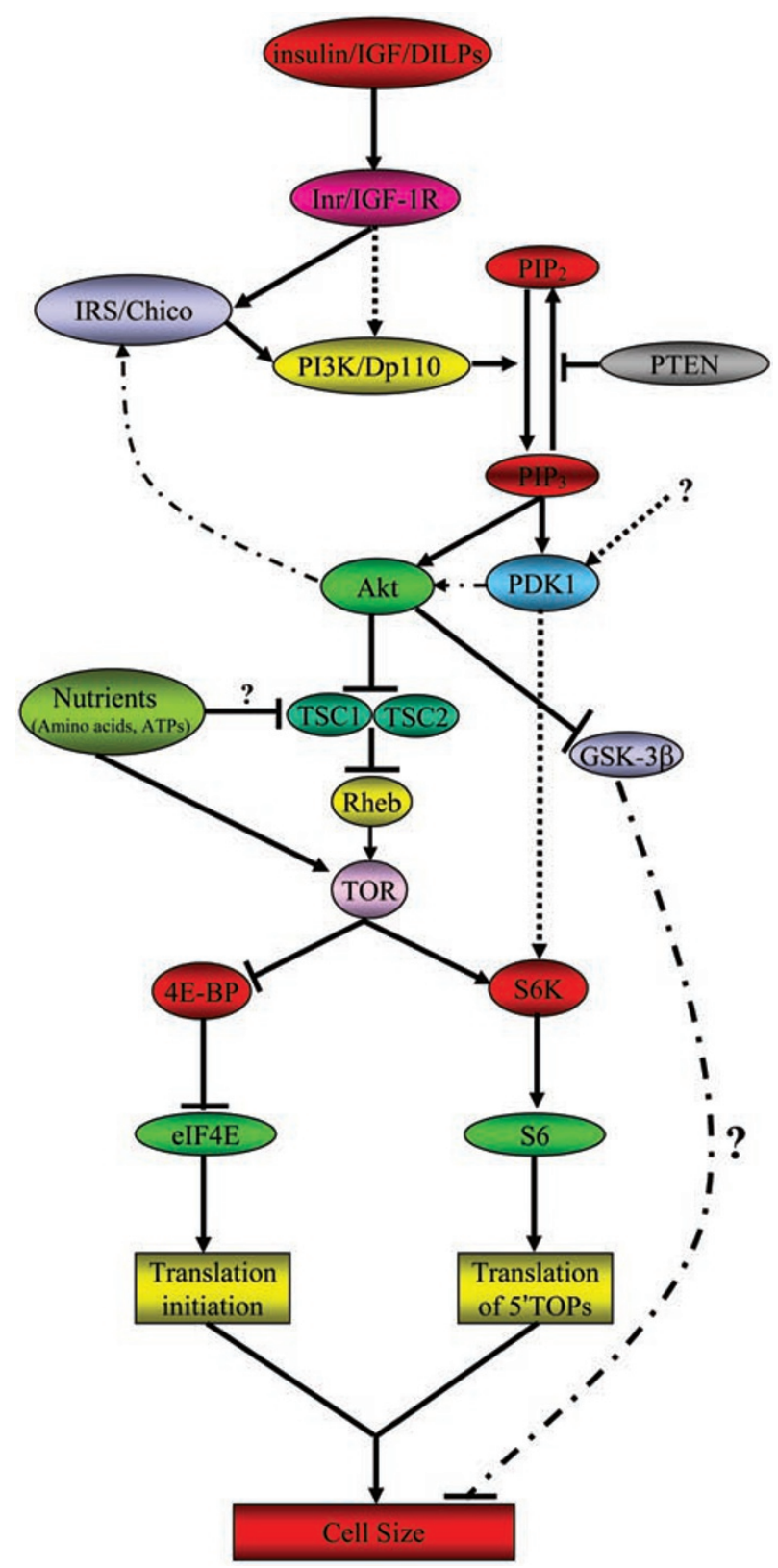

Figure 2 Insulin/PI3K/TOR signaling pathways for cell size control. Upon binding of insulin/IGF to the receptors, a signal is relayed via PI3K, lipid (PIP2, PIP3) and protein kinases (PDK1, Akt, TOR, S6K) that finally causes cell growth by activating the translation machinery and protein synthesis. Different connecting lines represent pathways found or confirmed in Drosophila (…..), mammals (--) or both (-). Lines with arrow-head means the gene stimulates downstream gene function, whereas lines with blunt line means the gene inhibits downstream gene function.

to $\mathrm{PIP}_{3}$ on the membrane. Association with $\mathrm{PIP}_{3}$ at the membrane brings these proteins into proximity and facilitates phosphorylation and activation of Akt by PDK1 [74].
On the other hand, a phosphatase and tumor suppressor, PTEN (phosphatase and tensin homolog), can antagonize PI3K function by dephosphorylating the phosphate at the 3-position of the lipid and converting PIP $_{3}$ back to $\mathrm{PIP}_{2}[75,76]$. Activated Akt can regulate phosphorylation of S6K and 4E-BP by directly binding to and phosphorylating the tumor suppressor TSC2 (tuberous sclerosis complex 2) [77-79]. Phosphorylation of TSC2 by Akt destabilizes the TSC1-TSC2 complex and inhibits the ability of TSC to suppress the phosphorylation of S6K and 4E-BP through inhibition of Rheb, resulting in enhanced phosphorylation of both S6K and 4E-BP [80-84]. Phosphorylation of S6K activates the protein, which can subsequently phosphorylate the ribosomal protein S6, leading to an increased translation of $5^{\prime}$ TOP (terminal oligopyrimidine tracts) mRNAs. These $5^{\prime}$ TOP sequences are found mostly in ribosomal protein mRNAs, suggesting that activation of S6K may cause an increase in protein synthesis. Phosphorylation of 4E-BP1 by TOR inactivates its function, which causes the release of its repression on eIF4E and, thereby, leads to enhanced global translation initiation. Therefore, insulin signaling stimulates cell growth and controls cell size by modulation of protein synthesis via the PI3K/TOR pathway. In addition, TOR can also mediate cell size changes induced by nutrient (amino acid, ATPs, etc) availability, possibly through TSC1/TSC2 or other pathways $[71,85]$.

Genetic studies have revealed functional similarities of the insulin/PI3K/TOR pathway in Drosophila and mammals. In general, inactivation of genes that promote the insulin/PI3K/TOR pathway including Inr, IRS1-2/ Chico, PI3K/Dp110, PDK1, Akt, TOR, and S6K, reduces cell, organ or organism size; whereas activation of several of these genes has the opposite effect [86-102]. Conversely, mutations in negative regulators of the pathway, such as PTEN, TSC1 or TSC2, increase cell or organ size; whereas overexpression of PTEN or both TSC1 and TSC2 causes reduced cell size or organ size (Figure 2) [76, 103-108]. In mice, overexpression of GSK-3 $\beta$, a downstream target of Akt (Figure 2), during brain development reduces brain size in transgenic mice by reducing cell size [109]. The mechanism for regulation of cell growth by GSK-3 $\beta$ is unknown (Figure 2).

Despite the strong functional parallel and conservation of the InR/PI3K/TOR pathways between Drosophila and mammals, there are some differences in the phenotypes caused by certain gene mutations in vivo. For example, Drosophila S6K mutants have reduced cell, organ and organism size, whereas S6K knock-out mice are only slightly reduced in size, where most of their cells are of normal size, except for pancreatic $\beta$-cells, which are smaller $[88,110]$. In addition, activation of dS6K in 
Drosophila requires dPDK1, but not dPI3K and dAkt [111], whereas transgenic mouse model clearly demonstrated that Akt is important for activation of S6K in cell size control [100, 102]. Furthermore, loss of PTEN causes increased cell size in all the tissues in Drosophila, whereas loss of PTEN only affects cell size in the brain rather than other tissues in mice $[76,112]$. The reasons for these differences are currently unknown. Recent studies in yeast show that Akt and TOR are thus far the only two genes in the insulin/PI3K/TOR pathways that are found to be involved in cell size control. Interestingly, like in multicellular organisms, loss of function of Akt or TOR also causes decreased cell growth and cell size in yeast [113-115].

\section{Cell cycle regulators}

Overexpression or loss-of-function of most cell cycle regulators does not affect cell growth and organ size. This is clearly demonstrated in the experiments directly manipulating the cell cycle in Drosophila imaginal discs. In these experiments, the cell cycle was deregulated in one compartment of the wing imaginal disc by manipulating the activities of the G1/S progression activators cyclin E or E2F and the inhibitor, Rb, and the G2/M progression activators $\mathrm{Cdc} 2$ and Cdc25/String. Surprisingly, activation of cyclin $\mathrm{E}$ or Cdc25/String in the posterior compartment increases cell cycle progression in the G1/ $\mathrm{S}$ and G2/M transitions, respectively, without any effect on cell proliferation, cell number and compartment size. Activation of $\mathrm{E} 2 \mathrm{~F}$ in the posterior compartment increases both cell proliferation and cell number but decreases cell size, resulting in constant compartment size. Conversely, activation of $\mathrm{Rb}$ or inactivation of $\mathrm{Cdc} 2$ in the posterior compartment leads to a decrease in cell number and an increase in cell size but no change in compartment size $[11,116]$. These results suggest that control of the cell cycle regulators may not be the key mechanism through which organ size is regulated.

However, studies in flies, mice, worms and plants suggest that the traditional cell cycle regulators, such as cyclin $\mathrm{D} / \mathrm{Cdk} 4$, might primarily function as the regulator of cell growth and cell size. Mice lacking either cyclin D or Cdk4 are substantially smaller than wild-type littermates [117, 118]. Similarly, although mutants for cyclin D are still not available, flies deficient for $\mathrm{Cdk} 4$ also have small body sizes [119]. Overexpression of cyclin $\mathrm{D} / \mathrm{Cdk} 4$ in the developing wing generates more cells that are of normal size [120], suggesting that both cell growth and cell proliferation are increased. When cyclin D and Cdk4 were co-expressed in postmitotic cells in the Drosophila eye disc, cell size was significantly increased [120]. Interestingly, recent studies on renal tubule epithelial hy- pertrophy further demonstrate that an increase in cell size induced by the activation of cyclin $\mathrm{D}$ is responsible for renal cell hypertrophy in response to injury in mice [121], suggesting that the role of cyclin $\mathrm{D} / \mathrm{Cdk}$ in cell growth control is evolutionarily conserved. However, how cyclin $\mathrm{D} / \mathrm{Cdk} 4$ regulates cell growth is still unknown.

\section{Ras, Rho, Rac, and myc - a second pathway regulating} cell and organ size?

Ras, Rho, Rac and myc have long been recognized as oncogenes and play important roles in the development of a variety of human cancers (for review, see [122-125]. However, recent studies suggest that they may regulate cell growth, cell size, organ and organism size through a unique pathway that may be dependent on or independent of the insulin signaling pathway (Figure 3).

In Drosophila, dmyc mutants reach the adult stage at smaller body size [126] due to reduced cell size and number [127]. Overexpression of dMyc increases cell size by increasing cell growth rate without affecting cell division rate [127]. Similarly, in mammals, adenovirusmediated overexpression of $c-m y c$ in the liver causes an increase in liver size due to enlarged hepatocyte cell size [128]. In addition, forced expression of c-myc in vitro and in vivo also increases cell size in lymphocytes both in cell culture and in mice $[129,130]$. However, although decreasing the level of $c-m y c$ leads to a corresponding reduction in mice body size, contrary to Drosophila dmyc mutants, this reduction is caused not by a decrease in cell size but by a decrease in cell number due to reduced cell proliferation [131]. It has been suggested that coordination of cell proliferation and cell growth may be more tightly controlled in mice than in Drosophila, which would allow cells to maintain a constant size so that organ size would be determined by the number of cell divisions. However, several reports oppose this possibility. First, overexpression of either $d m y c$ or c-myc can cause an increase in cell size rather than cell numbers in Drosophila or in mice, respectively, indicating that the primary function of $m y c$ is to modulate cell size. Second, the reduced body size of mice lacking genes for insulin/PI3K signaling, such as PDK1, can be also caused by a decrease in cell size rather than by changes in cell number or proliferation [101]. Third, modulation of cell size by cellular genes may be tissue-specific. As we mentioned above, an increase in cell size and organ size for mice lacking PTEN is only observed in the brain rather than other tissues [112], whereas a reduction in cell size is only observed in pancreatic $\beta$-cells in mice lacking S6K1 [110]. In the study by Trumpp et al. [131], cell number and size were only examined in spleen, lymph nodes and bone marrow cells. Therefore, it is still possible that 


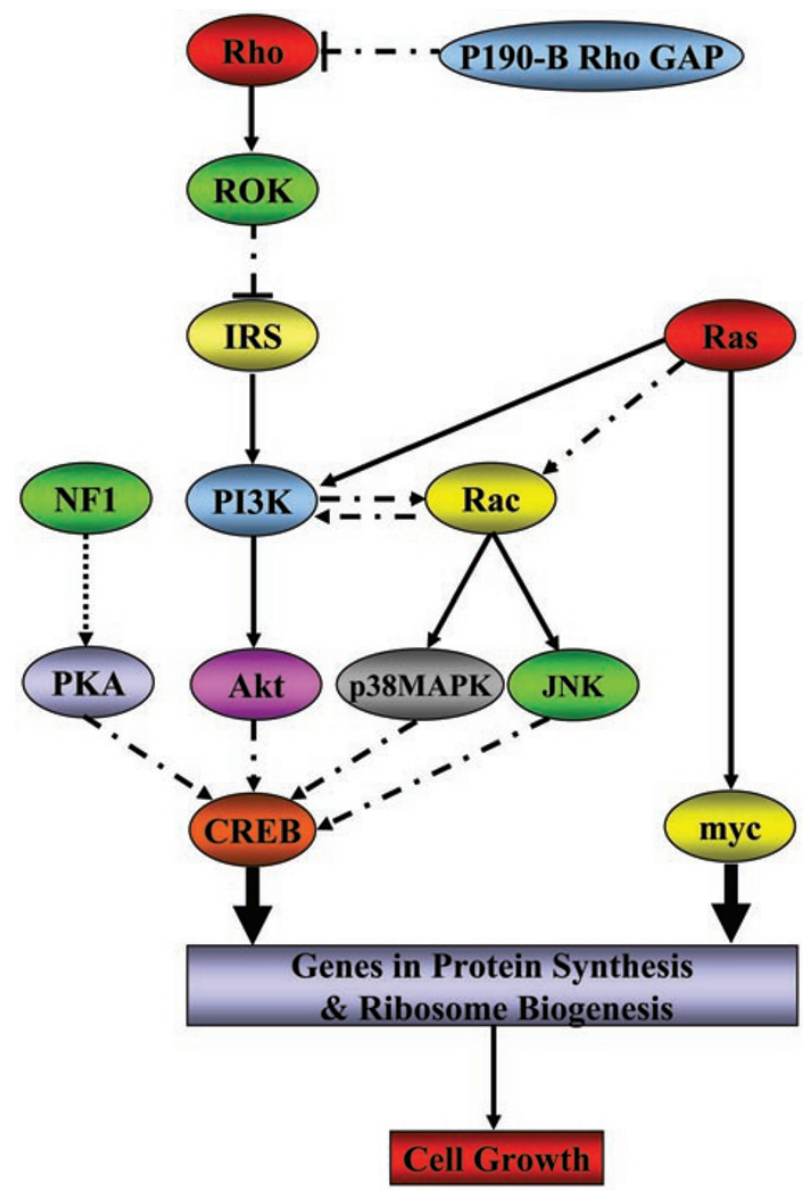

Figure 3 Rho, Rac, Ras and myc signaling pathways for cell growth control. Lines and symbols are as described in Figure 2.

decreased cell size can occur in other tissues. Whatever the reasons, current studies strongly suggest a role for $m y c$ in cell, organ and organism size control. Furthermore, several lines of evidence support the role of myc in cell growth control: (1) a Myc target gene, pitchoune, which encodes a DEAD box RNA helicase that may be involved in ribosome biogenesis, is also required for cell growth in Drosophila [132]; (2) overexpression of c-myc causes enhanced protein synthesis correlating with cell growth, but independent of cell cycle phase [129]; (3) Myc can induce a large set of genes functioning in ribosome biogenesis (nucleolin, and nucleophosmin) and protein synthesis (EEF1, eIF4E and eIF2 $\alpha$ ) [133, 134], which is necessary for cell growth.

Recently, a direct role for Ras in controlling cellular growth was found in Drosophila [135]. Cells lacking ras were smaller and had reduced growth rates. Conversely, overexpressing Ras (dRasV12) in clones of proliferating cells resulted in similar phenotypes as those after overexpressing dMyc [135]. Consistently, expression of activated Ras in mouse heart tissue also increases heart size as a result of cell enlargement [136]. Ras activates cell growth by either activating dMyc post-transcriptionally or activating PI3K (Figure 3; [135, 137, 138]). In addition, Ras may also regulate cell growth by activating Rac, another GTPase [139]. It has been shown that overexpression of constitutively active $\mathrm{rac} 1$ (V12 $\mathrm{rac} 1$ ) in neonatal cardiac myocytes results in an increase in cell size and enlarged heart [140]. Furthermore, the Rho GTPase was also suggested to be involved in cell size control. Mice lacking the Rho-inhibitory protein, p190B RhoGAP, are $30 \%$ reduced in size due to reduced cell size [141]. Loss of p190-B RhoGAP causes enhanced Rho activity, which subsequently inhibits IRS and PI3K function by inhibiting IRS activity through the Rho effector ROCK (Figure 3; [142]). Interestingly, the cell size defect can be rescued by expression of a constitutively activated CREB [141]. Mice deficient for CREB display a small animal phenotype similar to that of mice deficient for p190-B RhoGAP [143], suggesting that Rho and CREB may act in the same pathway in controlling cell and animal size. In addition, it has been shown that loss of function mutations in both NF1 and PKA result in reduced animal size in Drosophila [144], and CREB is known to be a substrate of PKA in mammalian cells [145]. Therefore, NF1 and PKA may regulate cell and body size through the modulation of CREB (Figure 3). The molecular mechanism by which CREB regulates cell and animal size is presently unknown. Like myc, CREB is also a transcription factor that can induce a variety of genes, including those involved in the regulation of metabolism [146]. Nevertheless, the crucial proteins mediating CREB regulation of cell growth remain to be identified.

In conclusion, Ras, Rho and Rac, which were previously regarded as GTPases and major regulators of cytoskeleton, may form a second pathway overlapping with or independent of the insulin signaling pathway and play an important role in the regulation of cell, organ and organism size. They may regulate animal size by regulating transcription factors, such as $m y c$ or $C R E B$, which can subsequently transactivate cellular genes involved in protein synthesis and metabolism during cell growth. Recent studies in yeast also suggest that transcriptional regulation by transcription factors plays very important roles in controlling cell size [147].

\section{Interaction between cell growth and cell division in cell and organ size control}

During the development of multicellular organisms, cell size is relatively constant in specific tissues even 
in rapidly proliferating tissues. Thus, cell proliferation and cell growth need to coordinate perfectly in order to maintain a constant cell size. However, it is still largely unknown how cell growth and division rates are coordinated to ensure the maintenance of cell size and organ size. Currently, four mechanisms have been proposed to explain the relationship between cell growth and cell division, each with some experimental support. The first mechanism is that cell growth is dominant to cell division [115]. The second mechanism is that cell proliferation inhibits cell growth during the cell cycle [148]. The third mechanism is that cell growth and cell division are controlled coordinately by a growth coordinator. The fourth mechanism is that cell growth and cell division are independently regulated.

The view for the first mechanism comes mostly from yeast and Drosophila genetic studies. In budding yeast, G1 cyclins must accumulate to critical cellular levels in order to start cell cycle progression from the G1/S transition, START. A G1 cyclin, Cln3, was found to be a critical mediator between cell growth and cell cycle progression. The $\operatorname{cln} 3 \mathrm{mRNA}$ has a long $5^{\prime}$ untranslated region ( $5^{\prime}$ UTR) that contains many short open reading frames (uORFs) whose function is to decelerate initiation of $\ln 3$ mRNA translation when few ribosomes are available in the cytoplasm. As the concentration of ribosomes correlates with growth rate, this mechanism provides a link between growth rate and the rate of $\mathrm{C} \ln 3$ synthesis. Under poor growth conditions, Cln3 levels are dramatically reduced due to frequent initiation from uORFs and reduced translation initiation from the $\operatorname{cln} 3$ start codon. However, under favorable growth conditions, Cln3 levels greatly increase, resulting in rapid transition through START [149]. A similar mechanism also exists in multicellular systems such as Drosophila, in which progression through G1/S and G2/M is controlled by the levels of cyclin E and Cdc25, respectively [150, 151]. Accelerating cell cycle progression by overexpression of either cyclin $\mathrm{E}$ and $\mathrm{Cdc} 25$ or the transcription factor E2F cannot change the growth rate, resulting in cells with reduced cell size [11]. This experimental result suggests that acceleration of the cell cycle cannot stimulate cell growth. On the other hand, several lines of evidence suggest that cyclin $\mathrm{E}$, like $\mathrm{Cln} 3$, may function to 'sense' growth signals to drive the cell cycle through G1/S. First, cyclin $\mathrm{E}$ levels are rate limiting. Overexpression of cyclin E can drive the cells passing through G1/S rapidly [11]. Second, cyclin E levels can be upregulated by enhanced growth rate induced by overexpression of $\mathrm{dMyc}$ or Ras [135]. Third, comparable to $\operatorname{cln} 3$, the $5^{\prime}$ UTR region of cyclin $E$ contains several uORFs [152]. A similar sensing mechanism that links cell growth to cell cycle progres- sion by $\mathrm{Cdc} 25$ for G2/M transition was also found in fission yeast [153].

The second mechanism in which cell division inhibits cell growth comes from studies in yeast and mammalian cells [148]. By measuring a single cell growth rate during the cell cycle progression in both yeast and mammalian cells, several groups have discovered that the cell growth rate during the cell cycle is not constant but changes during the cell cycle stages. The cell growth rate is high during G1 phase but is decreased during mitosis [154-157], suggesting that cell division may inhibit cell growth. It has been proposed that increased Cdk activity and polarized actin cytoskeleton during mitosis may be responsible for the inhibition of cell growth [148].

The third mechanism for regulated coordination of cell growth and cell division is supported by studies on organ size control in mammals and plants. When a TGF- $\beta$ superfamily gene, myostatin, was deleted in mice, the animals are significantly larger than wild-type animals. Most strikingly, muscle mass of mutant animals are 2-3 times greater than those of wild-type animals due to an increase in both cell number and cell size [158]. This suggests that myostatin normally inhibits both muscle cell growth and cell division. Further studies demonstrate that myostatin inhibits cell division by inducing Cdk inhibitor $p 21$ and inhibits cell growth by reducing protein synthesis $[159,160]$. Therefore, myostatin may function as a growth coordinator that coordinately regulates cell division and cell size. Since myostatin is only expressed in muscle cells, identification of genes similar to myostatin in other tissues will serve to confirm whether the regulation of animal size by a growth coordinator is a common mechanism in size control. Interestingly, a gene called $A N T$ with similar functions to myostatin has been also identified in Arabidopsis as a regulator of organ size control. ANT has been shown to define organ size by regulating the extent of cell proliferation coordinately with growth [8]. These results suggest that the coordinate control of cell growth and cell division may be a common mechanism for both animals and plants to control organ and organism size.

The fourth mechanism, where cell growth and cell proliferation are regulated separately, is supported by studies from mammalian cell culture system. In an attempt to examine how cell growth and cell division are coordinated in order to keep a constant cell size, Conlon et al. [161] examined cell growth and cell division after treatment of rat Schwann cells with glial growth factor (GGF). They found that GGF can stimulate cell cycle progression without promoting cell growth, further confirming studies in yeast and Drosophila that proliferation can not drive cell growth. Moreover, the authors also 
found that increasing the growth rate by IGF-1 treatment has no effect on cell cycle progression, suggesting cell growth and cell division are regulated separately. In fact, the uncoupling of cell growth and cell division are frequently observed during animal development, such as during the early embryonic stage when large embryos are divided into smaller cells without concomitant cell growth. However, whether this mechanism is commonly used in other settings or developmental stages remains to be determined.

\section{Roles of other genes involved in organ size control}

Besides the roles of cell proliferation, cell death, and cell growth in organ size control, recent studies suggest that cellular genes regulating pattern formation (e.g. $\mathrm{Wg}$ and Dpp, etc), cell-cell adhesion (e.g. Fat and Dachsous, etc), and cell polarity (e.g. scribble, stardust, fat, $L K B$, etc) also have dramatic effect on final organ size (for review see references $[162,163]$ and [106]). These genes may function as 'organ-size checkpoints' that regulate cell proliferation, cell death, and cell growth.

\section{Size control and human diseases}

\section{Cancer}

Although increases in cell proliferation and cell number are highly important in tumorigenesis, deregulation of size control may also play a role in human cancers. This is well illustrated in the study of three genes involved in size control as we described above, PTEN, TSC1 and TSC2. PTEN is a tumor suppressor gene that was found to be mutated in various human cancers including melanoma and glioblastomas, and in endometrial, prostate and breast cancers [164]. Most importantly, PTEN mutations are also found in the autosomal dominant hamartoma syndrome Cowden disease and Bannayan-Riley-Ruvalcaba syndrome. The hallmark features of Cowden disease include appearance of hamartoma-like overgrowths of various tissues, including skin, breast, intestine and brain, early in life. Lhermitte-Duclos disease is a component of Cowden disease. One of the major features of Lhermitte-Duclos disease is hamartoma in the brain and enlarged granule cells in the cerebellum, implying that inactivation of PTEN may be responsible for these phenotypes. Indeed, deletion of PTEN in mouse brain shows a cell-autonomous increase in brain soma cell size and brain size, which resembles LhermitteDuclos disease $[112,165]$. Therefore, deregulation of cell size and organ size due to dysfunction of PTEN in cell size control may be the original cause of LhermitteDuclos disease.
TSC is a relatively common heritable genetic disorder that occurs in approximately 1 in 6000 . It is characterized by the formation of hamartomas with giant cells in a wide variety of human tissues, including brain, skin, kidney, lung and heart $[166,167]$. Mutations of two tumor suppressor genes, TSC 1 and TSC 2, are found to be responsible for familial TSC [168, 169]. Interestingly, recent studies in Drosophila illustrate that loss-of-function mutations in TSC1 and TSC2 basically abolish size control in the animals. Cell or organ size is dramatically increased in cells or tissues mutant for either TSC1 or TSC2 [105-107], resembling clinical symptoms of TSC in humans.

Besides PTEN and TSC, dysfunction of other genes involved in size control, such as Akt and PI3K has also been reported in a wide variety of human cancers [170]. Moreover, many components of the Hippo-LATS signaling pathways, which play very important roles in size control, also function as tumor suppressor genes (e.g. Merlin, Mst1/2, and LATS1/2) or oncogenes (e.g. YAP and its paralog TAZ) (for detailed reviews, see references $[22,26-30,171-173])$. Together, these studies strongly suggest that dysregulation of size control may be important in the development of human cancers.

\section{Diabetes}

Loss of size control in the development of diabetes is clearly demonstrated in Akt2 and S6K knockout mice. Akt2-deficient mice are born normal, but soon develop phenotypes that recapitulate different aspects of clinical type 2 diabetes mellitus with defect in insulin-stimulated glucose disposal in peripheral tissues, insulin suppression of hepatic glucose production, and glucose-mediated insulin secretion by pancreatic $\beta$-cells. In addition, insulin levels are almost 8-fold higher in Akt2-deficient mice compared to wild-type mice. Consistent with this phenotype, Akt2-deficient mice have a dramatic increase in the size and number of pancreatic islets, which would compensate for hyperglycemia by producing more insulin [174]. The phenotype in S6K1-knockout mice is quite the opposite of what is observed in Akt2-knockout mice. Basal insulin levels are reduced in such mice. Injection of glucose has little effect on these levels, compared to wild-type mice, suggesting that S6K1-knockout mice have an insulin deficiency. Further analysis shows that the decreased insulin levels are caused by reduced pancreatic $\beta$-cell size rather than a decrease in $\beta$ cell number [110]. Consistent with these observations, $\beta$-cell-specific knockout of PDK1, which is an activator of S6K1 and AKT (Figure 2), also leads to decreases in $\beta$-cell size [175]. These experiments in mice strongly suggest that dysregulation of size control, especially in the case of $\beta$ 
cell size, may contribute greatly in the development of diabetes in humans.

\section{Organ hypertrophy or atrophy}

Uncontrolled cell or organ size in certain tissues, such as cardiac and renal tissues, may also cause organ hypertrophy or atrophy. A good example to illustrate this is hypertrophic cardiomyopathy (HCM). HCM is a relatively common genetic cardiac disease (1:500 in the general population). This relates largely to its recognition as the common cause of sudden death in the young. One of the major pathologies in HCM is cardiac hypertrophy [176]. Cardiac hypertrophy is caused by an enlargement of individual muscle cells, called cardiomyocytes, rather than by an increase in cell number. A recent study has shown that enhanced expression of several cellular genes associated with cell size control has been found in HCM patients. Interestingly, cardiomyocyte size was found to be correlated with the expression level of c-H-ras and cMyc [177], suggesting that c-H-ras and c-Myc may play a role in the hypertrophic mechanism in HCM by increasing cardiomyocyte size. This conclusion was further supported by another experiment in which overexpression of ras in cardiomyocytes induces enlarged cardiomyocyte size and cardiac hypertrophy [136]. Besides the roles of size control in HCM, increased cell size caused by activation of mTOR and S6K1 has also been shown to be responsible for glomerular hypertrophy in kidney $[178,179]$. Moreover, overexpression of tumor suppressor TSC1 or knockout of S6K1 causes muscle atrophy in mice [180].

\section{Conclusion}

Although the molecular mechanism of size control is still largely unknown, genetic studies in model systems, especially in Drosophila and mice, are helping us to unravel signal pathways regulating cell, organ, and organism size. Understanding size control mechanisms can answer not only some of the basic biological questions but also questions about human diseases, such as cancer and diabetes. With the increasing interest on size control in mammalian systems, the next few years will be seeing more exciting and encouraging discoveries.

\section{Acknowledgments}

The research in the author's laboratory is supported by funding from Canadian Institute of Health Research (CIHR), Canadian Breast Cancer Foundation (CBCF), Cancer Research Society (CRS, Canada), a New Investigator Award from CIHR, and an Early Researcher Award from Ontario Ministry of Research and Innovation, Canada, to Xiaolong Yang and NIH/NCI to Tian Xu. T X is an investigator of the Howard Hughes Medical Institute.

\section{References}

1 Twitty VC, Schwind JL. The growth of eyes and limbs transplanted heteroplastically between two species of Amblytoma. J Exp Zool 1931; 59:61-86.

2 Silber SJ. Growth of baby kidneys transplanted into adults. Surg Forum 1975; 26:579-582.

3 Francavilla A, Ove P, Polimeno L, et al. Regulation of liver size and regeneration: importance in liver transplantation. Transplant Proc 1988; 20:494-497.

4 Kawarasaki H, Makuuchi M, Ishisone S, et al. Partial liver transplantation from living related donors. Transplant Proc 1992; 24:1470-1472.

5 Starzl TE, Fung J, Tzakis A, et al. Baboon-to-human liver transplantation. Lancet 1993; 341:65-71.

6 Bryant PJ, Simpson P. Intrinsic and extrinsic control of growth in developing organs. $Q$ Rev Biol 1984; 59:387-415.

7 Tsonis PA. Regeneration in vertebrates. Dev Biol 2000; 221:273-284.

8 Mizukami Y, Fischer RL. Plant organ size control: AINTEGUMENTA regulates growth and cell numbers during organogenesis. Proc Natl Acad Sci USA 2000; 97:942-947.

9 Niklas K. Plant Allometry: The Scaling of Form and Process. The University of Chicago Press, 1994.

10 Conlon I, Raff M. Size control in animal development. Cell 1999; 96:235-244.

11 Neufeld TP, de la Cruz AF, Johnston LA, Edgar BA. Coordination of growth and cell division in the Drosophila wing. Cell 1998; 93:1183-1193.

12 Polyak K, Kato JY, Solomon MJ, et al. p27Kip1, a cyclin-Cdk inhibitor, links transforming growth factor-beta and contact inhibition to cell cycle arrest. Genes Dev 1994; 8:9-22.

13 Besson A, Assoian RK, Roberts JM. Regulation of the cytoskeleton: an oncogenic function for CDK inhibitors? Nat Rev Cancer 2004; 4:948-955.

14 Besson A, Dowdy SF, Roberts JM. CDK inhibitors: cell cycle regulators and beyond. Dev Cell 2008; 14:159-169.

15 Nakayama K, Ishida N, Shirane M, et al. Mice lacking p27(Kip1) display increased body size, multiple organ hyperplasia, retinal dysplasia, and pituitary tumors. Cell 1996; 85:707-720.

16 Kiyokawa H, Kineman RD, Manova-Todorova KO, et al. Enhanced growth of mice lacking the cyclin-dependent kinase inhibitor function of p27(Kip1). Cell 1996; 85:721-732.

17 Fero ML, Rivkin M, Tasch M, et al. A syndrome of multiorgan hyperplasia with features of gigantism, tumorigenesis, and female sterility in p27(Kip1)-deficient mice. Cell 1996; 85:733-744.

18 Nakayama K, Nagahama H, Minamishima YA, et al. Targeted disruption of Skp2 results in accumulation of cyclin $\mathrm{E}$ and $\mathrm{p} 27$ (Kip1), polyploidy and centrosome overduplication. EMBO J 2000; 19:2069-2081.

19 Li X, Perissi V, Liu F, Rose DW, Rosenfeld MG. Tissuespecific regulation of retinal and pituitary precursor cell proliferation. Science 2002; 297:1180-1183.

$20 \mathrm{Xu} \mathrm{T}$, Wang W, Zhang S, Stewart RA, Yu W. Identifying tumor suppressors in genetic mosaics: the Drosophila lats 
gene encodes a putative protein kinase. Development 1995; 121:1053-1063.

21 Tao W, Zhang S, Turenchalk GS, et al. Human homologue of the Drosophila melanogaster lats tumour suppressor modulates CDC2 activity. Nat Genet 1999; 21:177-181.

22 Zeng Q, Hong W. The emerging role of the hippo pathway in cell contact inhibition, organ size control, and cancer development in mammals. Cancer Cell 2008; 13:188-192.

23 Buttitta LA, Edgar BA. How size is controlled: from Hippos to Yorkies. Nat Cell Biol 2007; 9:1225-1227.

24 Cook M, Tyers M. Size control goes global. Curr Opin Biotechnol 2007; 18:341-350.

25 Dong J, Feldmann G, Huang J, et al. Elucidation of a universal size-control mechanism in Drosophila and mammals. Cell 2007; 130:1120-1133.

26 Harvey K, Tapon N. The Salvador-Warts-Hippo pathway - an emerging tumour-suppressor network. Nat Rev Cancer 2007; 7:182-191.

27 Pan D. Hippo signaling in organ size control. Genes Dev 2007; 21:886-897.

28 Yin F, Pan D. Fat flies expanded the hippo pathway: a matter of size control. Sci STKE 2007; 380:pe12.

29 Zhao B, Lei QY, Guan KL. The Hippo-YAP pathway: new connections between regulation of organ size and cancer. Curr Opin Cell Biol 2008; 20:638-646.

30 Visser S, Yang X. Identification of LATS transcriptional targets in HeLa cells using whole human genome oligonucleotide microarray. Gene 2010; 449:22-29.

31 Qi C, Zhu YT, Hu L, Zhu YJ. Identification of Fat4 as a candidate tumor suppressor gene in breast cancers. Int $J$ Cancer 2009; 124:793-798.

32 Lau YK, Murray LB, Houshmandi SS, Xu Y, Gutmann DH, $\mathrm{Yu}$ Q. Merlin is a potent inhibitor of glioma growth. Cancer Res 2008; 68:5733-5742.

33 Benhamouche S, Curto M, Saotome I, et al. Nf2/Merlin controls progenitor homeostasis and tumorigenesis in the liver. Genes Dev 2010; 24:1718-1730.

34 Okada T, You L, Giancotti FG. Shedding light on Merlin's wizardry. Trends Cell Biol 2007; 17:222-229.

35 Chan EH, Nousiainen M, Chalamalasetty RB, Schafer A, Nigg EA, Sillje HH. The Ste20-like kinase Mst2 activates the human large tumor suppressor kinase Lats1. Oncogene 2005; 24:2076-2086.

36 Lee JH, Kim TS, Yang TH, et al. A crucial role of WW45 in developing epithelial tissues in the mouse. EMBO J 2008; 27:1231-1242.

37 Zhao B, Wei X, Li W, et al. Inactivation of YAP oncoprotein by the Hippo pathway is involved in cell contact inhibition and tissue growth control. Genes Dev 2007; 21:2747-2761.

38 Hao Y, Chun A, Cheung K, Rashidi B, Yang X. Tumor suppressor LATS1 is a negative regulator of oncogene YAP. $J$ Biol Chem 2008; 283:5496-5509.

39 Hong JH, Hwang ES, McManus MT, et al. TAZ, a transcriptional modulator of mesenchymal stem cell differentiation. Science 2005; 309:1074-1078.

40 Wang K, Degerny C, Xu M, Yang XJ. YAP, TAZ, and Yorkie: a conserved family of signal-responsive transcriptional coregulators in animal development and human disease. Biochem Cell Biol 2009; 87:77-91.
41 Chow A, Hao Y, Yang X. Molecular characterization of human homologs of yeast MOB1. Int J Cancer 2010; 126:20792089.

42 Lei QY, Zhang H, Zhao B, et al. TAZ promotes cell proliferation and epithelial-mesenchymal transition and is inhibited by the hippo pathway. Mol Cell Biol 2008; 28:2426-2436.

43 Zhou D, Conrad C, Xia F, et al. Mst1 and Mst2 maintain hepatocyte quiescence and suppress hepatocellular carcinoma development through inactivation of the Yap1 oncogene. Cancer Cell 2009; 16:425-438.

44 Lee KP, Lee JH, Kim TS, et al. The Hippo-Salvador pathway restrains hepatic oval cell proliferation, liver size, and liver tumorigenesis. Proc Natl Acad Sci USA 2010; 107:8248-8253.

45 Buttitta LA, Edgar BA. Mechanisms controlling cell cycle exit upon terminal differentiation. Curr Opin Cell Biol 2007; 19:697-704.

46 Chenn A, Walsh CA. Regulation of cerebral cortical size by control of cell cycle exit in neural precursors. Science 2002; 297:365-369.

47 Green DR, Evan GI. A matter of life and death. Cancer Cell 2002; 1:19-30.

48 Martinou JC, Dubois-Dauphin M, Staple JK, et al. Overexpression of BCL-2 in transgenic mice protects neurons from naturally occurring cell death and experimental ischemia. Neuron 1994; 13:1017-1030.

49 Hakem R, Hakem A, Duncan GS, et al. Differential requirement for caspase 9 in apoptotic pathways in vivo. Cell 1998; 94:339-352.

50 Kuida K, Haydar TF, Kuan CY, et al. Reduced apoptosis and cytochrome c-mediated caspase activation in mice lacking caspase 9. Cell 1998; 94:325-337.

51 Slane JM, Lee HS, Vorhees CV, Zhang J, Xu M. DNA fragmentation factor 45 deficient mice exhibit enhanced spatial learning and memory compared to wild-type control mice. Brain Res 2000; 867:70-79.

52 Porteous S, Torban E, Cho NP, et al. Primary renal hypoplasia in humans and mice with PAX2 mutations: evidence of increased apoptosis in fetal kidneys of Pax2(1Neu) $+/-$ mutant mice. Hum Mol Genet 2000; 9:1-11.

53 Godley LA, Kopp JB, Eckhaus M, Paglino JJ, Owens J, Varmus HE. Wild-type p53 transgenic mice exhibit altered differentiation of the ureteric bud and possess small kidneys. Genes Dev 1996; 10:836-850.

54 Halder G, Callaerts P, Flister S, Walldorf U, Kloter U, Gehring WJ. Eyeless initiates the expression of both sine oculis and eyes absent during Drosophila compound eye development. Development 1998; 125:2181-2191.

55 Fausto N. Liver regeneration: from laboratory to clinic. Liver Transpl 2001; 7:835-844.

56 Schrum LW, Bird MA, Salcher O, et al. Autocrine expression of activated transforming growth factor-beta(1) induces apoptosis in normal rat liver. Am J Physiol Gastrointest Liver Physiol 2001; 280:G139-148.

57 Bursch W, Lauer B, Timmermann-Trosiener I, Barthel G, Schuppler J, Schulte-Hermann R. Controlled death (apoptosis) of normal and putative preneoplastic cells in rat liver following withdrawal of tumor promoters. Carcinogenesis 1984; 5:453-458.

58 Ledda-Columbano GM, Columbano A, Coni P, Faa G, Pani P. 
Cell deletion by apoptosis during regression of renal hyperplasia. Am J Pathol 1989; 135:657-662.

59 Sanders S, Thorgeirsson SS. Phenobarbital promotes liver growth in c-myc/TGF-alpha transgenic mice by inducing hypertrophy and inhibiting apoptosis. Carcinogenesis 1999; 20:41-49.

60 Knight CG, Patel MN, Azevedo RB, Leroi AM. A novel mode of ecdysozoan growth in Caenorhabditis elegans. Evol Dev 2002; 4:16-27.

61 Day SJ, Lawrence PA. Measuring dimensions: the regulation of size and shape. Development 2000; 127:2977-2987.

62 Frankenhauser G. The effects of changes in chromosome number on amphibian development. $Q$ Rev Biol 1945; 20:241251.

63 Minamishima YA, Nakayama K, Nakayama K. Recovery of liver mass without proliferation of hepatocytes after partial hepatectomy in Skp2-deficient mice. Cancer Res 2002; 62:995-999.

64 Bogre L, Magyar Z, Lopez-Juez E. New clues to organ size control in plants. Genome Biol 2008; 9:226.

65 Kondorosi E, Roudier F, Gendreau E. Plant cell-size control: growing by ploidy? Curr Opin Plant Biol 2000; 3:488-492.

66 Galitski T, Saldanha AJ, Styles CA, Lander ES, Fink GR. Ploidy regulation of gene expression. Science 1999; 285:251254.

67 Morita K, Flemming AJ, Sugihara Y, et al. A Caenorhabditis elegans TGF-beta, DBL-1, controls the expression of LON-1, a PR-related protein, that regulates polyploidization and body length. EMBO J 2002; 21:1063-1073.

$68 \mathrm{Su}$ TT, O'Farrell PH. Size control: cell proliferation does not equal growth. Curr Biol 1998; 8:R687-R689.

69 Stocker H, Hafen E. Genetic control of cell size. Curr Opin Genet Dev 2000; 10:529-535.

70 Potter CJ, Huang H, Xu T. Drosophila Tsc1 functions with Tsc2 to antagonize insulin signaling in regulating cell growth, cell proliferation, and organ size. Cell 2001; 105:357-368.

71 Schmelzle T, Hall MN. TOR, a central controller of cell growth. Cell 2000; 103:253-262.

72 Sarbassov DD, Ali SM, Sabatini DM. Growing roles for the mTOR pathway. Curr Opin Cell Biol 2005; 17:596-603.

73 Edgar BA. From small flies come big discoveries about size control. Nat Cell Biol 1999; 1:E191-E193.

74 Lawlor MA, Alessi DR. PKB/Akt: a key mediator of cell proliferation, survival and insulin responses? J Cell Sci 2001; 114:2903-2910.

75 Maehama T, Dixon JE. The tumor suppressor, PTEN/ MMAC1, dephosphorylates the lipid second messenger, phosphatidylinositol 3,4,5-trisphosphate. J Biol Chem 1998; 273:13375-13378.

76 Huang H, Potter CJ, Tao W, et al. PTEN affects cell size, cell proliferation and apoptosis during Drosophila eye development. Development 1999; 126:5365-5372.

77 Inoki K, Li Y, Zhu T, Wu J, Guan KL. TSC2 is phosphorylated and inhibited by Akt and suppresses mTOR signalling. Nat Cell Biol 2002; 4:648-657.

78 Manning BD, Tee AR, Logsdon MN, Blenis J, Cantley LC. Identification of the tuberous sclerosis complex-2 tumor suppressor gene product tuberin as a target of the phosphoinositide 3-kinase/akt pathway. Mol Cell 2002; 10:151-162.
79 Potter CJ, Pedraza LG, Xu T. Akt regulates growth by directly phosphorylating Tsc2. Nat Cell Biol 2002; 4:658-665.

80 Zhang Y, Gao X, Saucedo LJ, Ru B, Edgar BA, Pan D. Rheb is a direct target of the tuberous sclerosis tumour suppressor proteins. Nat Cell Biol 2003; 5:578-581.

81 Garami A, Zwartkruis FJ, Nobukuni T, et al. Insulin activation of Rheb, a mediator of mTOR/S6K/4E-BP signaling, is inhibited by TSC1 and 2. Mol Cell 2003; 11:1457-1466.

82 Inoki $\mathrm{K}, \mathrm{Li} \mathrm{Y,} \mathrm{Xu} \mathrm{T,} \mathrm{Guan} \mathrm{KL.} \mathrm{Rheb} \mathrm{GTPase} \mathrm{is} \mathrm{a} \mathrm{direct} \mathrm{target}$ of TSC2 GAP activity and regulates mTOR signaling. Genes Dev 2003; 17:1829-1834.

83 Saucedo LJ, Gao X, Chiarelli DA, Li L, Pan D, Edgar BA. Rheb promotes cell growth as a component of the insulin/ TOR signalling network. Nat Cell Biol 2003; 5:566-571.

84 Stocker H, Radimerski T, Schindelholz B, et al. Rheb is an essential regulator of S6K in controlling cell growth in Drosophila. Nat Cell Biol 2003; 5:559-565.

85 Gao X, Zhang Y, Arrazola P, et al. Tsc tumour suppressor proteins antagonize amino-acid-TOR signalling. Nat Cell Biol 2002; 4:699-704.

86 Liu JP, Baker J, Perkins AS, Robertson EJ, Efstratiadis A. Mice carrying null mutations of the genes encoding insulinlike growth factor I (Igf-1) and type 1 IGF receptor (Igflr). Cell 1993; 75:59-72.

87 Tamemoto H, Kadowaki T, Tobe K, et al. Insulin resistance and growth retardation in mice lacking insulin receptor substrate-1. Nature 1994; 372:182-186.

88 Shima H, Pende M, Chen Y, Fumagalli S, Thomas G, Kozma SC. Disruption of the $\mathrm{p} 70(\mathrm{~s} 6 \mathrm{k}) / \mathrm{p} 85(\mathrm{~s} 6 \mathrm{k})$ gene reveals a small mouse phenotype and a new functional S6 kinase. EMBO J 1998; 17:6649-6659.

89 Withers DJ, Gutierrez JS, Towery H, et al. Disruption of IRS2 causes type 2 diabetes in mice. Nature 1998; 391:900-904.

90 Bohni R, Riesgo-Escovar J, Oldham S, et al. Autonomous control of cell and organ size by CHICO, a Drosophila homolog of vertebrate IRS1-4. Cell 1999; 97:865-875.

91 Montagne J, Stewart MJ, Stocker H, Hafen E, Kozma SC, Thomas G. Drosophila S6 kinase: a regulator of cell size. Science 1999; 285:2126-2129.

92 Verdu J, Buratovich MA, Wilder EL, Birnbaum MJ. Cell-autonomous regulation of cell and organ growth in Drosophila by Akt/PKB. Nat Cell Biol 1999; 1:500-506.

93 Weinkove D, Neufeld TP, Twardzik T, Waterfield MD, Leevers SJ. Regulation of imaginal disc cell size, cell number and organ size by Drosophila class I(A) phosphoinositide 3-kinase and its adaptor. Curr Biol 1999; 9:1019-1029.

94 Shioi T, Kang PM, Douglas PS, et al. The conserved phosphoinositide 3-kinase pathway determines heart size in mice. EMBO J 2000; 19:2537-2548.

95 Oldham S, Stocker H, Laffargue M, Wittwer F, Wymann M, Hafen E. The Drosophila insulin/IGF receptor controls growth and size by modulating PtdInsP(3) levels. Development 2002; 129:4103-4109.

96 Zhang H, Stallock JP, Ng JC, Reinhard C, Neufeld TP. Regulation of cellular growth by the Drosophila target of rapamycin dTOR. Genes Dev 2000; 14:2712-2724.

97 Brogiolo W, Stocker H, Ikeya T, Rintelen F, Fernandez R, Hafen E. An evolutionarily conserved function of the Drosophila insulin receptor and insulin-like peptides in growth con- 
trol. Curr Biol 2001; 11:213-221.

98 Chen WS, Xu PZ, Gottlob K, et al. Growth retardation and increased apoptosis in mice with homozygous disruption of the Akt1 gene. Genes Dev 2001; 15:2203-2208.

99 Rintelen F, Stocker H, Thomas G, Hafen E. PDK1 regulates growth through Akt and S6K in Drosophila. Proc Natl Acad Sci USA 2001; 98:15020-15025.

100 Tuttle RL, Gill NS, Pugh W, et al. Regulation of pancreatic beta-cell growth and survival by the serine/threonine protein kinase Akt1/PKBalpha. Nat Med 2001; 7:1133-1137.

101 Lawlor MA, Mora A, Ashby PR, et al. Essential role of PDK1 in regulating cell size and development in mice. EMBO J 2002; 21:3728-3738.

102 Shioi T, McMullen JR, Kang PM, et al. Akt/protein kinase $\mathrm{B}$ promotes organ growth in transgenic mice. Mol Cell Biol 2002; 22:2799-2809.

103 Goberdhan DC, Paricio N, Goodman EC, Mlodzik M, Wilson C. Drosophila tumor suppressor PTEN controls cell size and number by antagonizing the Chico/PI3-kinase signaling pathway. Genes Dev 1999; 13:3244-3258.

104 Gao X, Neufeld TP, Pan D. Drosophila PTEN regulates cell growth and proliferation through PI3K-dependent and -independent pathways. Dev Biol 2000; 221:404-418.

105 Tapon N, Ito N, Dickson BJ, Treisman JE, Hariharan IK. The Drosophila tuberous sclerosis complex gene homologs restrict cell growth and cell proliferation. Cell 2001; 105:345-355.

106 Potter CJ, Xu T. Mechanisms of size control. Curr Opin Genet Dev 2001; 11:279-286.

107 Gao X, Pan D. TSC1 and TSC2 tumor suppressors antagonize insulin signaling in cell growth. Genes Dev 2001; 15:13831392.

$108 \mathrm{Xu}$ Z, Stokoe D, Kane LP, Weiss A. The inducible expression of the tumor suppressor gene PTEN promotes apoptosis and decreases cell size by inhibiting the PI3K/Akt pathway in Jurkat T cells. Cell Growth Differ 2002; 13:285-296.

109 Spittaels K, Van den Haute C, Van Dorpe J, et al. Neonatal neuronal overexpression of glycogen synthase kinase-3 beta reduces brain size in transgenic mice. Neuroscience 2002; 113:797-808.

110 Pende M, Kozma SC, Jaquet M, et al. Hypoinsulinaemia, glucose intolerance and diminished beta-cell size in S6K1deficient mice. Nature 2000; 408:994-997.

111 Radimerski T, Montagne J, Rintelen F, et al. dS6K-regulated cell growth is $\mathrm{dPKB} / \mathrm{dPI}(3) \mathrm{K}$-independent, but requires dPDK1. Nat Cell Biol 2002; 4:251-255.

112 Backman SA, Stambolic V, Suzuki A, et al. Deletion of Pten in mouse brain causes seizures, ataxia and defects in soma size resembling Lhermitte-Duclos disease. Nat Genet 2001; 29:396-403.

113 Helliwell SB, Howald I, Barbet N, Hall MN. TOR2 is part of two related signaling pathways coordinating cell growth in Saccharomyces cerevisiae. Genetics 1998; 148:99-112.

114 Jorgensen P, Nishikawa JL, Breitkreutz BJ, Tyers M. Systematic identification of pathways that couple cell growth and division in yeast. Science 2002; 297:395-400.

115 Jorgensen P, Tyers M. How cells coordinate growth and division. Curr Biol 2004; 14:R1014-1027.

116 Weigmann K, Cohen SM, Lehner CF. Cell cycle progression, growth and patterning in imaginal discs despite inhibition of cell division after inactivation of Drosophila Cdc2 kinase. Development 1997; 124:3555-3563.

117 Rane SG, Dubus P, Mettus RV, et al. Loss of Cdk4 expression causes insulin-deficient diabetes and Cdk4 activation results in beta-islet cell hyperplasia. Nat Genet 1999; 22:44-52.

118 Fantl V, Stamp G, Andrews A, Rosewell I, Dickson C. Mice lacking cyclin D1 are small and show defects in eye and mammary gland development. Genes Dev 1995; 9:2364-2372.

119 Meyer CA, Jacobs HW, Datar SA, Du W, Edgar BA, Lehner CF. Drosophila Cdk4 is required for normal growth and is dispensable for cell cycle progression. EMBO J 2000; 19:45334542.

120 Datar SA, Jacobs HW, de la Cruz AF, Lehner CF, Edgar BA. The Drosophila cyclin D-Cdk4 complex promotes cellular growth. EMBO J 2000; 19:4543-4554.

121 Preisig P. A cell cycle-dependent mechanism of renal tubule epithelial cell hypertrophy. Kidney Int 1999; 56:1193-1198.

122 Dang CV. c-Myc target genes involved in cell growth, apoptosis, and metabolism. Mol Cell Biol 1999; 19:1-11.

123 Bar-Sagi D, Hall A. Ras and Rho GTPases: a family reunion. Cell 2000; 103:227-238.

124 Macaluso M, Russo G, Cinti C, Bazan V, Gebbia N, Russo A. Ras family genes: an interesting link between cell cycle and cancer. J Cell Physiol 2002; 192:125-130.

125 Sahai E, Marshall CJ. RHO-GTPases and cancer. Nat Rev Cancer 2002; 2:133-142.

126 Gallant P, Shiio Y, Cheng PF, Parkhurst SM, Eisenman RN. Myc and Max homologs in Drosophila. Science 1996; 274:1523-1527.

127 Johnston LA, Prober DA, Edgar BA, Eisenman RN, Gallant P. Drosophila myc regulates cellular growth during development. Cell 1999; 98:779-790.

128 Kim S, Li Q, Dang CV, Lee LA. Induction of ribosomal genes and hepatocyte hypertrophy by adenovirus-mediated expression of c-Myc in vivo. Proc Natl Acad Sci USA 2000; 97:11198-11202.

129 Iritani BM, Eisenman RN. c-Myc enhances protein synthesis and cell size during B lymphocyte development. Proc Natl Acad Sci USA 1999; 96:13180-13185.

130 Schuhmacher M, Staege MS, Pajic A, et al. Control of cell growth by c-Myc in the absence of cell division. Curr Biol 1999; 9:1255-1258.

131 Trumpp A, Refaeli Y, Oskarsson T, et al. c-Myc regulates mammalian body size by controlling cell number but not cell size. Nature 2001; 414:768-773.

132 Zaffran S, Chartier A, Gallant P, et al. A Drosophila RNA helicase gene, pitchoune, is required for cell growth and proliferation and is a potential target of d-Myc. Development 1998; 125:3571-3584.

133 Schmidt EV. The role of c-myc in cellular growth control. Oncogene 1999; 18:2988-2996.

134 Boon K, Caron HN, van Asperen R, et al. N-myc enhances the expression of a large set of genes functioning in ribosome biogenesis and protein synthesis. EMBO J 2001; 20:13831393.

135 Prober DA, Edgar BA. Ras1 promotes cellular growth in the Drosophila wing. Cell 2000; 100:435-446.

136 Hunter JJ, Tanaka N, Rockman HA, Ross J Jr, Chien KR. Ventricular expression of a MLC-2v-ras fusion gene induces 
cardiac hypertrophy and selective diastolic dysfunction in transgenic mice. J Biol Chem 1995; 270:23173-23178.

137 Sears R, Leone G, DeGregori J, Nevins JR. Ras enhances Myc protein stability. Mol Cell 1999; 3:169-179.

138 Prober DA, Edgar BA. Interactions between Ras1, dMyc, and dPI3K signaling in the developing Drosophila wing. Genes Dev 2002; 16:2286-2299.

139 Walsh AB, Bar-Sagi D. Differential activation of the Rac pathway by Ha-Ras and K-Ras. J Biol Chem 2001; 276:1560915615.

140 Pracyk JB, Tanaka K, Hegland DD, et al. A requirement for the rac1 GTPase in the signal transduction pathway leading to cardiac myocyte hypertrophy. J Clin Invest 1998; 102:929937.

141 Sordella R, Classon M, Hu KQ, et al. Modulation of CREB activity by the Rho GTPase regulates cell and organism size during mouse embryonic development. Dev Cell 2002; 2:553565.

142 Begum N, Sandu OA, Ito M, Lohmann SM, Smolenski A. Active Rho kinase (ROK-alpha) associates with insulin receptor substrate-1 and inhibits insulin signaling in vascular smooth muscle cells. J Biol Chem 2002; 277:6214-6222.

143 Rudolph D, Tafuri A, Gass P, Hammerling GJ, Arnold B, Schutz G. Impaired fetal T cell development and perinatal lethality in mice lacking the cAMP response element binding protein. Proc Natl Acad Sci USA 1998; 95:4481-4486.

144 The I, Hannigan GE, Cowley GS, Reginald S, Zhong Y, Gusella JF, Hariharan IK, Bernards A. Rescue of a Drosophila NF1 mutant phenotype by protein kinase A. Science 1997; 276:791-794.

145 Johannessen M, Delghandi MP, Moens U. What turns CREB on? Cell Signal 2004; 16:1211-1227.

146 Mayr B, Montminy M. Transcriptional regulation by the phosphorylation-dependent factor CREB. Nat Rev Mol Cell Biol 2001; 2:599-609.

147 Rupes I. Checking cell size in yeast. Trends Genet 2002; 18:479-485

148 Goranov AI, Amon A. Growth and division-not a one-way road. Curr Opin Cell Biol 2010; 22:6.

149 Polymenis M, Schmidt EV. Coupling of cell division to cell growth by translational control of the G1 cyclin CLN3 in yeast. Genes Dev 1997; 11:2522-2531.

150 Edgar BA, O'Farrell PH. The three postblastoderm cell cycles of Drosophila embryogenesis are regulated in G2 by string. Cell 1990; 62:469-480.

151 Knoblich JA, Sauer K, Jones L, Richardson H, Saint R, Lehner CF. Cyclin E controls S phase progression and its downregulation during Drosophila embryogenesis is required for the arrest of cell proliferation. Cell 1994; 77:107-120.

152 Richardson HE, O'Keefe LV, Reed SI, Saint R. A Drosophila G1-specific cyclin E homolog exhibits different modes of expression during embryogenesis. Development 1993; 119:673690.

153 Daga RR, Jimenez J. Translational control of the cdc25 cell cycle phosphatase: a molecular mechanism coupling mitosis to cell growth. J Cell Sci 1999; 112 Part 18:3137-3146.

154 Wilker EW, van Vugt MA, Artim SA, et al. 14-3-3sigma Controls Mitotic Translation to Facilitate Cytokinesis. Nature 2007; 446:329-332.
155 Baumgartner S, Tolic-Norrelykke IM. Growth pattern of single fission yeast cells is bilinear and depends on temperature and DNA synthesis. Biophys $J$ 2009; 96:4336-4347.

156 Goranov AI, Cook M, Ricicova M, et al. The rate of cell growth is governed by cell cycle stage. Genes Dev 2009; 23:1408-1422.

157 Tzur A, Kafri R, LeBleu VS, Lahav G, Kirschner MW. Cell growth and size homeostasis in proliferating animal cells. Science 2009; 325:167-171.

158 McPherron AC, Lawler AM, Lee SJ. Regulation of skeletal muscle mass in mice by a new TGF-beta superfamily member. Nature 1997; 387:83-90.

159 Thomas M, Langley B, Berry C, et al. Myostatin, a negative regulator of muscle growth, functions by inhibiting myoblast proliferation. J Biol Chem 2000; 275:40235-40243.

160 Taylor WE, Bhasin S, Artaza J, et al. Myostatin inhibits cell proliferation and protein synthesis in $\mathrm{C} 2 \mathrm{C} 12$ muscle cells. Am J Physiol Endocrinol Metab 2001; 280:E221-228.

161 Conlon IJ, Dunn GA, Mudge AW, Raff MC. Extracellular control of cell size. Nat Cell Biol 2001; 3:918-921.

162 Grusche FA, Degoutin J, Richardson HE, Harvey KF. The Salvador/Warts/Hippo pathway controls regenerative tissue growth in Drosophila melanogaster. Dev Biol 2011; 350:255266.

163 Leevers, McNeill. Controlling the size of organs and organisms. Curr Opin Cell Biol 2005; 17:604-609.

164 Simpson L, Parsons R. PTEN: life as a tumor suppressor. Exp Cell Res 2001; 264:29-41.

165 Kwon $\mathrm{CH}$, Zhu X, Zhang J, et al. Pten regulates neuronal soma size: a mouse model of Lhermitte-Duclos disease. Nat Genet 2001; 29:404-411.

166 Young J, Povey S. The genetic basis of tuberous sclerosis. Mol Med Today 1998; 4:313-319.

167 Napolioni V, Curatolo P. Genetics and molecular biology of tuberous sclerosis complex. Curr Genomics 2008; 9:475-487.

168 van Slegtenhorst M, de Hoogt R, Hermans C, et al. Identification of the tuberous sclerosis gene TSC1 on chromosome 9q34. Science 1997; 277:805-808.

169 Maheshwar MM, Cheadle JP, Jones AC, et al. The GAPrelated domain of tuberin, the product of the TSC2 gene, is a target for missense mutations in tuberous sclerosis. Hum Mol Genet 1997; 6:1991-1996.

170 Vivanco I, Sawyers CL. The phosphatidylinositol 3-Kinase AKT pathway in human cancer. Nat Rev Cancer 2002; 2:489501.

171 Hergovich A, Hemmings BA. Mammalian NDR/LATS protein kinases in hippo tumor suppressor signaling. Biofactors 2009; 35:338-345.

172 Edgar BA. From cell structure to transcription: Hippo forges a new path. Cell 2006; 124:267-273.

173 Hariharan IK. Growth regulation: a beginning for the hippo pathway. Curr Biol 2006; 16:R1037-1039.

$174 \mathrm{Cho} \mathrm{H,} \mathrm{Mu} \mathrm{J,} \mathrm{Kim} \mathrm{JK,} \mathrm{et} \mathrm{al.} \mathrm{Insulin} \mathrm{resistance} \mathrm{and} \mathrm{a} \mathrm{diabetes}$ mellitus-like syndrome in mice lacking the protein kinase Akt2 (PKB beta). Science 2001; 292:1728-1731.

175 Hashimoto N, Kido Y, Uchida T, et al. Ablation of PDK1 in pancreatic beta cells induces diabetes as a result of loss of beta cell mass. Nat Genet 2006; 38:589-593.

176 Marian AJ, Roberts R. The molecular genetic basis for hyper- 
trophic cardiomyopathy. J Mol Cell Cardiol 2001; 33:655670.

177 Kai H, Muraishi A, Sugiu Y, et al. Expression of proto-oncogenes and gene mutation of sarcomeric proteins in patients with hypertrophic cardiomyopathy. Circ Res 1998; 83:594601 .

178 Chen JK, Chen J, Neilson EG, Harris RC. Role of mammalian target of rapamycin signaling in compensatory renal hypertrophy. J Am Soc Nephrol 2005; 16:1384-1391.

179 Sakaguchi M, Isono M, Isshiki K, Sugimoto T, Koya D,
Kashiwagi A. Inhibition of mTOR signaling with rapamycin attenuates renal hypertrophy in the early diabetic mice. Biochem Biophys Res Commun 2006; 340:296-301.

180 Wan M, Wu X, Guan KL, Han M, Zhuang Y, Xu T. Muscle atrophy in transgenic mice expressing a human TSC1 transgene. FEBS Lett 2006; 580:5621-5627.

181 Ohanna M, Sobering AK, Lapointe T, et al. Atrophy of S6K1(-/-) skeletal muscle cells reveals distinct mTOR effectors for cell cycle and size control. Nat Cell Biol 2005; 7:286294. 